\title{
Voltammetric determination of extreme standard Gibbs ion transfer energy
}

\author{
Astrid J. Olaya, Manuel A. Méndez, Fernando Cortes-Salazar, Hubert H. Girault * \\ Laboratoire d'Electrochimie Physique et Analytique, Station 6, Ecole Polytechnique Fédérale de Lausanne, CH-1015 Lausanne, Switzerland
}

\section{A R T I C L E I N F O}

\section{Article history:}

Received 18 December 2009

Received in revised form 23 March 2010

Accepted 25 March 2010

Available online 27 March 2010

\section{Keywords:}

Standard Gibbs energy of transfer

Standard transfer potential

Micro-interface

Microhole

Hydrophobic ions

Hydrophilic ions

\begin{abstract}
A B S T R A C T
A voltammetric methodology to determine the standard Gibbs energy of transfer of highly hydrophobic and hydrophilic ions has been developed. The electrochemical cell used includes a water|1,2-dichloroethane micro-interface supported on a microhole in a thin polymer film separating an electrolyte-free aqueous phase and an organic phase with an electrolyte at low concentrations. The limiting current and the half-wave potential of these organic ions were determined by fitting the initial part of the ion transfer wave. The methodology was validated using ions with known thermodynamic data, and applied to very hydrophobic and very hydrophilic ions that usually cannot be observed within the potential window.
\end{abstract}

(C) 2010 Elsevier B.V. All rights reserved.

\section{Introduction}

Because of its relevance in the understanding of ion transfer across cellular channels and in solvent extraction processes among others fields, the kinetic and thermodynamic aspects of charge transfer processes at the interface between two immiscible electrolyte solutions (ITIES) have been widely investigated by electrochemical techniques [1-4]. In particular, liquid|liquid micro-interfaces offer several advantages in comparison with larger interfaces such as a significant reduction of the ohmic potential drop, a reduction of the capacitive currents, and steady-state responses [5-8]. Indeed, whether using micro-ITIES supported by a laser-drilled microhole in a thin film [6-12] or at the tip micropipettes [9,13-15] it has been shown that these micro-interfaces are very useful both for thermodynamic and kinetic measurements [5-8,11,12,16]. By comparison with microholes, voltammetric studies with micropipettes have to consider asymmetric diffusion fields and account for a relatively high electrical resistance within the pipette [8].

In charge-transfer kinetic studies, an excess of the supporting electrolyte is normally used in both phases [14]. However, it has been shown that Oldham's theory for steady-state voltammetry at hemispherical electrodes [17] can be applied for micro-ITIES systems with low concentration or in absence of supporting electrolyte $[5,6,8-10,14,18]$. The difference between these two steady-state systems is that in the case of metallic electrodes, the transport of species toward the electrode is given only by diffusion and the charged product is transported from the electrode by dif-

\footnotetext{
* Corresponding author. Tel.: +41 21693 3145; fax: +41 216933667 .

E-mail address: hubert.girault@epfl.ch (H.H. Girault).
}

fusion and migration, whilst it is the opposite in the case of micro-ITIES under conditions of diluted supporting electrolyte in the organic phase [6].

The transfer potential of the supporting electrolyte ions in either phase determines the size of the potential window at ITIES $[3,6,14]$. Taking into account that such transfer potential is given by the Gibbs energy of transfer $\left(\Delta G_{\text {tr }}^{0^{\prime}}\right)$, ions with large absolute values of $\Delta G_{\mathrm{tr}}^{0^{\prime}}$ (i.e. highly hydrophilic and lipophilic ions) are usually chosen in order to increase the size of the potential window $[3,6,14]$. For instance, organic ions like tetrakis(4-chlorophenyl)borate $\left(\mathrm{TPBCl}^{-}\right) \quad[14,15]$, tetrakis-(pentafluorophenyl)-borate $\left(\mathrm{TB}^{-}\right)[12,19,20]$ and bis(triphenylphosphoranylidene)-ammonium $\left(\mathrm{BA}^{+}\right)[19,20]$ are used as supporting electrolytes in the organic phase. The knowledge of the standard transfer potential of these ions is necessary to calculate the Galvani potential difference across the liquid-liquid interfaces when it is controlled by the distribution of all of ions in the system as in shake-flask experiments $[19,20]$. However, such potentials have not been reported so far due to the difficulty in investigating the transfer of such a lipophilic ions [6]. To circumvent this difficulty, micro-ITIES in the absence of supporting electrolyte, either in the aqueous or in the organic phase, have been suggested $[6,14]$. In this way, Wilke et al. [6] have developed a theoretical model to determine the $\Delta G_{\mathrm{tr}}^{0^{\prime}}$ of highly hydrophilic ions as $\mathrm{Li}^{+}, \mathrm{K}^{+}$and $\mathrm{Na}^{+}$at water|nitrobenzene microinterfaces with and without supporting electrolyte in the aqueous phase and with a $10 \mathrm{mM}$ solution of bis(triphenylphosphoranylidene)ammonium dicarbollyl-cobaltate (III) (PNPDCC) as supporting electrolyte in the organic phase [6]. The model is based on Oldham's theory [17,21], in which the migration of the ions is taken into account for systems under unsupported conditions. 
In this work, the $\Delta G_{\mathrm{tr}}^{0^{\prime}}$ of ions that usually limit the potential window $\left(\mathrm{BA}^{+}, \mathrm{TB}^{-}, \mathrm{OH}^{-}\right.$and $\left.\mathrm{H}^{+}\right)$was determined at the water|DCE micro-ITIES without supporting electrolyte in the aqueous phase and with a very low concentration of electrolyte in the organic phase (BATPBCl and BATB $0.5 \mathrm{mM}$ and $0.05 \mathrm{mM}$ ). Taking into account that the limiting current and therefore the half-wave potential of these ions are not directly available from the voltammograms, these parameters were determined by fitting the onset of the transfer waves, where the current-potential curve is linear, using the model developed by Wilke [6] In order to validate the values obtained by the methodology proposed in this work, we also determined the $\Delta G_{\mathrm{tr}}^{0^{\prime}}$ of hydrophilic ions such as, $\mathrm{Cs}^{+}, \mathrm{Li}^{+}, \mathrm{I}^{-}, \mathrm{Br}^{-}, \mathrm{Cl}^{-}, \mathrm{ClO}_{4}^{-}$and the $\Delta G_{\mathrm{tr}}^{0^{\prime}}$ of lipophilic ions such as $\mathrm{TBA}^{+}, \mathrm{THA}^{+}$and $\mathrm{TOA}^{+}$(tetra-(butyl, hexyl and octyl)-ammonium). The $\Delta G_{\text {tr }}^{0^{\prime}}$ values obtained agree with those reported by other authors [19,22-24]. The best results are obtained when the separation between the $\Delta G_{\mathrm{tr}}^{0^{\prime}}$ of the ions transferring consecutively is between 0.35 and $0.45 \mathrm{~V}$ approximately. The $\Delta G_{\mathrm{tr}}^{0^{\prime}}$ values of $\mathrm{BA}^{+}$and $\mathrm{TB}^{-}$obtained from the different systems studied differ only in $\pm 4 \mathrm{~kJ} \mathrm{~mol}^{-1}$, and the slope values obtained from the fitting are equal to the theoretical value of $F / R T$, i.e. $39.6 \mathrm{~V}^{-1}$ (at $20^{\circ} \mathrm{C}$ ). This suggests that the methodology proposed in this work is reliable to determine the $\Delta G_{\mathrm{tr}}^{0^{\prime}}$ of either highly hydrophobic or hydrophilic ions.

\section{Experimental}

\subsection{Chemicals and reagents}

All solvents and chemicals were used as received without further purification. Bis(triphenylphosphoranylidine)ammonium chloride (BACl 98\%), potassium tetrakis(4-chlorophenyl)-borate (KTPBCl 98\%), lithium tetrakis(pentafluorophenyl)-borate ethyl etherate (LiTB purum), tetradecylammonium chloride (TDACl 95\%), sodium tetraphenylborate (NaTPB 99.5\%), tetramethylammonium chloride (TMACl 98\%), tetrabutylammonium bromide (TBABr 99\%), lithium hydroxide (99\%) and diethyl ether (99.5\%) were purchased from Fluka. Tetrahexylammonium bromide (THABr 99\%) and tetraoctylammonium bromide (TOABr 98\%) were obtained from Acros. Chlorhydric acid (37-38\%) and 1,2-dicholoroethane (grade HPLC) were purchased from Merck and Applichem respectively. Bis(triphenylphosphoranylidine)ammonium tetrakis(4chlorophenyl)-borate (BATPBCl), bis(triphenylphosphoranylidine)ammonium tetrakis(pentafluorophenyl)-borate (BATB) and tetradecylammonium tetraphenylborate were prepared by metathesis of $1: 1$ mixtures of $\mathrm{BACl}$ and $\mathrm{KTPBCl}, \mathrm{BACl}$ and LiTB, and TDACl and NaTPB respectively in methanol-water mixtures $(V: V=2.1)$, followed by recrystallization from acetone. In order to transfer $\mathrm{TBA}^{+}, \mathrm{THA}^{+}$and $\mathrm{TOA}^{+}$from the organic to the aqueous phase, tetrabutylammonium tetrakis(pentafluorophenyl)-borate (TBATB), tetrahexyl-ammonium tetrakis(pentafluorophenyl)-borate (THATB) and tetraoctylammonium tetrakis(pentafluorophenyl)-borate (TOATB) were prepared by metathesis $1: 1$ of $\mathrm{TBABr}$, $\mathrm{THABr}$ and $\mathrm{TOABr}$ with LiTB in mixtures ethanol-water $(V: V=2: 1,2: 1$ and $1: 4$, respectively). The THATB and TOATB are room-temperature ionic liquids which were separated from the reaction mixture by liquid|liquid extraction with diethyl ether followed by washing with ultra pure water $\left(18.2 \mathrm{M} \Omega \mathrm{cm}^{-1}\right)$ until $\mathrm{Br}^{-}$ was not detected by addition of $\mathrm{AgNO}_{3}$ solution in the washing solution. The solvent was evaporated using a vacuum pump at $30{ }^{\circ} \mathrm{C}$ overnight. In this work, these ionic liquids were dissolved

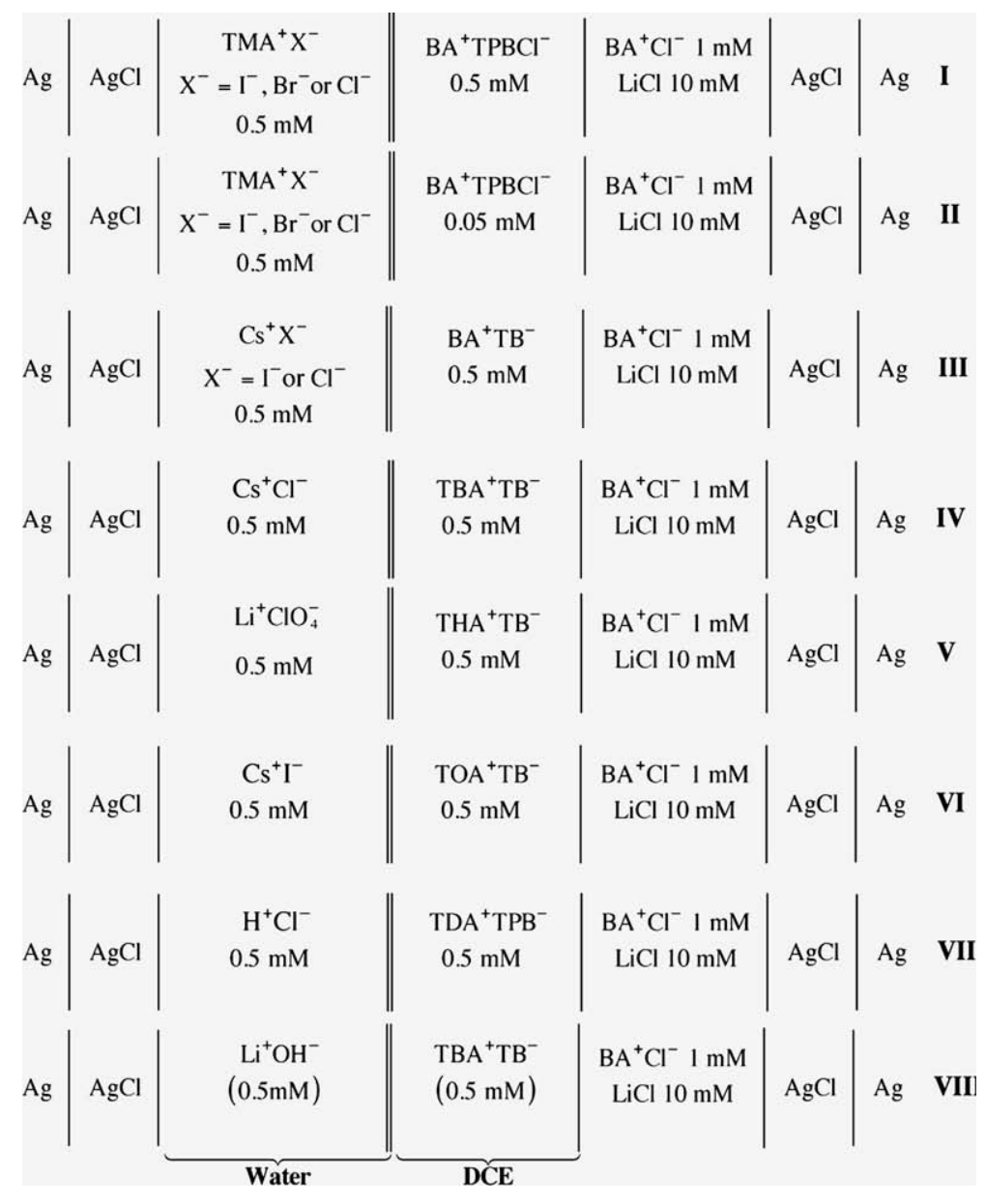




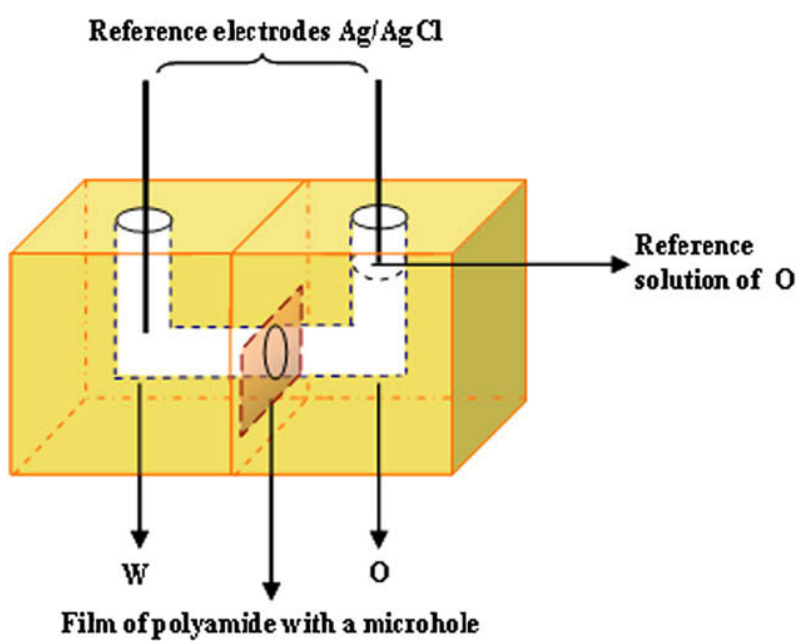

Fig. 1. Schematic diagram of a typical two-electrode cell used in the experiments. The microhole was drilled into a $25 \mu \mathrm{m}$ thick film of polyamide (Kapton ${ }^{\circledR}$ ). W: water phase; 0 : organic phase.

in DCE in order to use them as supporting electrolytes in the organic phase, however, they can be used directly to form water|ionic liquid interfaces [25-28]. All the aqueous solutions were prepared with ultra pure water. The solution of LiOH $5 \mathrm{mM}(\mathrm{pH}=13.7)$ was prepared with water degassed with argon in order to displace the $\mathrm{CO}_{2}$ from the solution.

\subsection{Electrochemical cell}

The micro-interface between the two immiscible solutions (water|DCE) was supported in a microhole drilled in a $25 \mu \mathrm{m}$ thick polyamide film (Kapton ${ }^{\circledR}$, Dupont) purchased from Goodfellow (UK) by UV-photoablation through a metallic mask using a $193 \mathrm{~nm}$ ArF excimer laser beam (Lambda Physik, Göttingen, Germany, fluence $=0.2 \mathrm{~J}$, frequency $=50 \mathrm{~Hz}$ ). As a consequence of the drilling by photoablation the actual shape of the microhole is conical. The diameters of the laser entrance and exit were determined to be $24 \mu \mathrm{m}$ and $12 \mu \mathrm{m}( \pm 1 \mu \mathrm{m})$ respectively. In all the experiments the aqueous phase was introduced first than the organic phase [2] and the smallest diameter opening was located on the organic side.

The microhole was located in vertical position between the two immiscible solutions (water|DCE) using a Teflon cell with two $\mathrm{Ag} \mid \mathrm{AgCl}$ reference electrodes (Fig. 1). For all the experiments, the voltammetric scan rate was $10 \mathrm{mV} / \mathrm{s}$ and the temperature was $20^{\circ} \mathrm{C}$. IR compensation for IR drop was not applied.

The transfer of $\mathrm{BA}^{+}$was studied using the cells I-III and that of $\mathrm{TB}^{-}$was studied using the cells IV-VI. The transfer of $\mathrm{H}^{+}$and $\mathrm{OH}^{-}$ was studied using the cells VII and VIII, respectively.

\section{Results}

Taking into account that in all the cases the cell was filled by the aqueous phase first, it is assumed the micro-interface was located on the organic side, in accordance with Peulon et al. [2]. In addition, being the ratio between the diameter of the microhole and its longitude $(d / L)$ less than 1 , one can ensure a good reproducibility of the obtained data [2].

In order to determine the limiting current $\left(I_{\mathrm{lim}}\right)$, the half-wave potential $\left(\Delta_{0}^{\mathrm{w}} \phi_{1 / 2}\right)$ and the slope theoretically equal to $F / R T$ constant for each ion in the cells, the model described by Wilke [6] for systems under unsupported conditions was used. In which, because of the migration of the ions, the actual half-wave potential
( $\Delta_{\mathrm{o}}^{\mathrm{w}} \phi_{1 / 2}$ obtained by $I=I_{\lim } / 2$ ) is shifted with respect to the usual half-wave potential $\left(\Delta_{\mathrm{o}}^{\mathrm{w}} \phi_{1 / 2}\right)$ [21], according to the following [6]:

$\Delta_{\mathrm{o}}^{\mathrm{w}} \phi_{1 / 2, i}^{\prime}-\Delta_{\mathrm{o}}^{\mathrm{w}} \phi_{1 / 2, i}=\frac{R T}{z_{i} F} \ln \left[2^{-z_{i} / z_{j}}\left(1-\frac{z_{i}}{z_{j}}\right)\right]$

where $i^{z i+}$ and $j^{z j-}$ are electrolytes present only in the aqueous phase, $R$ is the constant of the ideal gases, $T$ the temperature and $F$ the Faraday constant.Taking into account that the condition $z_{i}=-z_{j}$ is fulfilled in all the systems under study, the $I_{\text {lim }}$ for a planar microdiskshaped interface can be expressed as $[21,29,6]$ :

$I_{\lim }=8 z_{i} F D_{i, w} c_{i}$

where $D_{i, w}$ and $c_{i}$ are the diffusion coefficient and the concentration of ion $i$ respectively. And the total potential difference $\left(\Delta_{0}^{\mathrm{w}} \phi_{1 / 2}\right)$ as a function of the cell current, can be expressed as:

$\Delta_{\mathrm{o}}^{\mathrm{w}} \phi=\Delta_{\mathrm{o}}^{\mathrm{w}} \phi_{1 / 2, i}+\frac{R T}{z_{i} F} \ln \left[2\left(\frac{I}{I_{\lim }-I}\right)\left(\frac{I_{\lim }}{I_{\lim }-I}\right)\right]$

In this way, the current as a function of the potential difference reads [6]:

$$
\begin{aligned}
I= & I_{\lim }\left[1+\exp \left[\frac{z_{i} F}{R T}\left(\Delta_{\mathrm{o}}^{\mathrm{w}} \phi-\Delta_{\mathrm{o}}^{\mathrm{w}} \phi_{1 / 2, i}\right)\right]\right. \\
& \left.-\sqrt{\left[-1+\exp \left[\frac{z_{i} F}{R T}\left(\Delta_{\mathrm{o}}^{\mathrm{w}} \phi-\Delta_{\mathrm{o}}^{\mathrm{w}} \phi_{1 / 2, i}\right)\right]\right]^{2}-1}\right]
\end{aligned}
$$

The parameters $z_{i} F / R T, \Delta_{\mathrm{o}}^{\mathrm{w}} \phi_{1 / 2}$ and $I_{\text {lim }}$, were determined using the Eq. (4) by fitting of the initial part of the transfer of the corresponding ion (linear section before reaching the limiting current). The program used to fit the data was Mathematica 7.0.

Finally, knowing the $\Delta_{0}^{\mathrm{w}} \phi_{1 / 2}$, the standard Gibbs transfer energy is defined as:

$\Delta G_{\mathrm{tr}, i}^{0^{\prime}, \mathrm{i} \rightarrow \mathrm{w}}=-z_{i} F \Delta_{\mathrm{o}}^{\mathrm{w}} \phi_{1 / 2}$
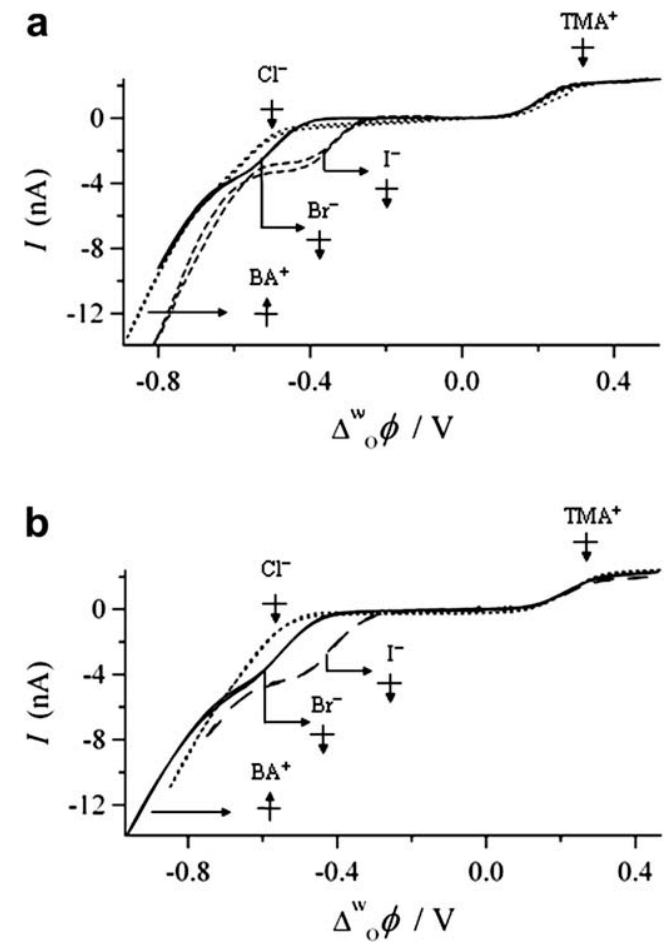

Fig. 2. Cyclic voltammogram obtained at the water|DCE interface with (a) cell I and (b) cell II. Scan rate: $10 \mathrm{mV} \mathrm{s}^{-1}$. The voltammograms were calibrated with respect to the $\Delta_{0}^{\mathrm{w}} \phi_{1 / 2}$ of $\mathrm{TMA}^{+}(0.18 \mathrm{~V}[22])$ 
Fig. 2a and $\mathrm{b}$ shows the voltammograms obtained for the systems in cells I and II, respectively. In all the cases the fitting were made taking the first $160 \mathrm{mV}$ of the linear section of the current-potential curve for each ion. A reference ion whose $\Delta_{\mathrm{o}}^{\mathrm{w}} \phi_{1 / 2}$ is known to be less positive to the one of interest (e.g. $\mathrm{Cs}^{+}$was chosen as reference ion to study the transfer of $\mathrm{TB}^{-}$) was introduced for two reasons: In order to calibrate the potential window with respect to the $\Delta_{0}^{\mathrm{w}} \phi_{1 / 2}$ obtained from the fitting of the reference ion, and, because the $I_{\text {lim }}$ obtained for the reference ion is subtracted from the second wave corresponding to the target ion, in order to do the fitting for this wave using the same approach. As a result, reliable standard ion transfer potentials can be obtained since direct evaluation of the slope theoretically equal to $F / R T$ is done for an standard case as well as for the target ion.

As an example, Fig. 3 illustrates the fitting obtained for the transfer of $\mathrm{I}^{-}, \mathrm{Br}^{-}$and $\mathrm{BA}^{+}$in the cell $\mathrm{I}$. It is clear that the obtained fittings are in agreement with the experimental data, which was observed for all the systems. Table 1 summarizes the results obtained for the ions in cells I and II. We can see that the dispersion of the $\Delta_{\mathrm{o}}^{\mathrm{w}} \phi_{1 / 2}$ for all the ions is $\pm 5 \mathrm{mV}$, which is in the order of the experimental error. Despite the absence of electrolyte in the aqueous phase and considering that the concentration of the organic electrolyte is very low $(0.5 \mathrm{mM}$ and $0.05 \mathrm{mM})$, the half-wave potentials obtained for $\mathrm{I}^{-}, \mathrm{Br}^{-}$and $\mathrm{Cl}^{-}$in the cell $\mathrm{I}$ as well as in cell II are in agreement with the values reported by other authors: $-0.34,-0.45$ and -0.53 [23], respectively.

The slope obtained for $\mathrm{TMA}^{+}$is equal to the theoretical value $39.6 \mathrm{~V}^{-1}$ for all the systems in cell I (using TMAI, TMABr or TMACl in the aqueous phase), which indicates that the ion transfer process is reversible. On the other hand, for the systems in cell II where the concentration of the supporting electrolyte is 10 times lower compared to cell I, the obtained constants are between $30 \mathrm{~V}^{-1}$ and $35 \mathrm{~V}^{-1}$, indicating simultaneous influence of the $I R$ drop and the migration mass transport. Consequently, for the other experiments the concentration of the supporting electrolyte in the organic phase was kept constant at $0.5 \mathrm{mM}$, where these effects are negligible.

In the case of cell I, only the transfer of $\mathrm{BA}^{+}$using TMAI in the aqueous phase yielded a slope of $39.6 \mathrm{~V}^{-1}$. When using TMABr or $\mathrm{TMACl}$ in the aqueous phase, the values obtained were lower. This indicates that the transfer of the ions $\mathrm{Br}^{-}$and $\mathrm{Cl}^{-}$is too close to the
Table 1

Results obtained from the fitting using Eq. (4) for cells I and II. The potential window was calibrated with respect to the $\Delta_{0}^{\mathrm{w}} \phi_{1 / 2}$ of $\mathrm{TMA}^{+}(0.18 \mathrm{~V}$ [22]). For all systems (TMAI, TMABr and TMACl) the limiting current of $\mathrm{TMA}^{+}$is around $2.3 \mathrm{nA}$.

\begin{tabular}{|c|c|c|c|c|c|c|}
\hline \multirow[b]{2}{*}{ Ion } & \multicolumn{3}{|c|}{ Cell I (BATPBCl $0.5 \mathrm{mM}$ ) } & \multicolumn{3}{|c|}{ Cell II (BATPBCl $0.05 \mathrm{mM}$ ) } \\
\hline & $\mathrm{I}^{-}$ & $\mathrm{Br}^{-}$ & $\mathrm{Cl}^{-}$ & $\overline{\mathrm{I}^{-}}$ & $\mathrm{Br}^{-}$ & $\mathrm{Cl}^{-}$ \\
\hline$I_{\lim } / \mathrm{nA}$ & -3.4 & -3.7 & -4.1 & -4.1 & -4.6 & -3.9 \\
\hline$\Delta_{0}^{\mathrm{w}} \phi_{1 / 2}(\mathrm{~V})$ & -0.32 & -0.46 & -0.53 & -0.36 & -0.49 & -0.56 \\
\hline$F / R T\left(\mathrm{~V}^{-1}\right)$ & 39.6 & 36.2 & 34.7 & 31.7 & 28.2 & 30.1 \\
\hline$\Delta G_{\mathrm{tr}}^{0^{\prime}, \mathrm{w} \rightarrow \mathrm{o}}\left(\mathrm{kJ} \mathrm{mol}^{-1}\right)$ & 30.9 & 44.3 & 51.1 & 34.7 & 47.2 & 54.0 \\
\hline Ion & $\mathrm{BA}^{+}$ & $\mathrm{BA}^{+}$ & $\mathrm{BA}^{+}$ & $\mathrm{BA}^{+}$ & $\mathrm{BA}^{+}$ & $\mathrm{BA}^{+}$ \\
\hline$I_{\lim }(\mathrm{nA})$ & -7.0 & -7.4 & -7.4 & -4.6 & -4.4 & -4.4 \\
\hline$\Delta_{\mathrm{o}}^{\mathrm{w}} \phi_{1 / 2}(\mathrm{~V})$ & -0.67 & -0.70 & -0.70 & -0.67 & -0.71 & -0.70 \\
\hline$F / R T\left(\mathrm{~V}^{-1}\right)$ & 39.6 & 28.7 & 28.9 & 24.4 & 29.6 & 29.3 \\
\hline$\Delta G_{\mathrm{tr}}^{0^{\prime}, \mathrm{w} \rightarrow \mathrm{o}}\left(\mathrm{kJ} \mathrm{mol}^{-1}\right)$ & -64.6 & -67.5 & -67.5 & -64.6 & -68.5 & -67.5 \\
\hline
\end{tabular}

transfer of $\mathrm{BA}^{+}$and both currents interfere with each other. Consequently, it is clear that in order to ensure the measurement of reliable data, the transfer potentials of ions transferring consecutively should be separated enough, as has been observed previously [14]. In addition, taking into account that the $I_{\lim }$ of the reference ion is subtracted from the wave of the target ion, the separation between the two ions should not be too large in order to distinguish the two waves easily. Therefore, in order to obtain reliable $\Delta_{0}^{\mathrm{w}} \phi_{1 / 2}$ values, a separation between $0.35 \mathrm{~V}$ and $0.45 \mathrm{~V}$ is suggested. This was taken into account for the following experiments.

The $\Delta_{\mathrm{o}}^{\mathrm{w}} \phi_{1 / 2}$ of the $\mathrm{TPBCl}^{-}$was not determined since it was not possible to collect enough reliable data for the fitting due to the noisy current recorded. This is a consequence of the remarkable tendency of $\mathrm{TPBCl}^{-}$to form ion pairs [19,30,31], which leads to adsorption processes and interfacial instability upon its desorption from the interface.

Fig. 4 and Table 2 summarize the results obtained for cell II. In this case the dispersion in the values of $\Delta_{0}^{\mathrm{w}} \phi_{1 / 2}$ for all the ions is $\pm 4 \mathrm{mV}$. The slope for the transfer of $\mathrm{BA}^{+}$presents the same behavior as that in cell $\mathrm{I}$, since with $\mathrm{I}^{-}$the constant for both ions $\left(\mathrm{BA}^{+}\right.$and $\left.\mathrm{I}^{-}\right)$ is equal to $39.6 \mathrm{~V}^{-1}$, while with $\mathrm{Cl}^{-}$this value decreases. This confirms the observation made before about the adequate separation of the transfer potentials.

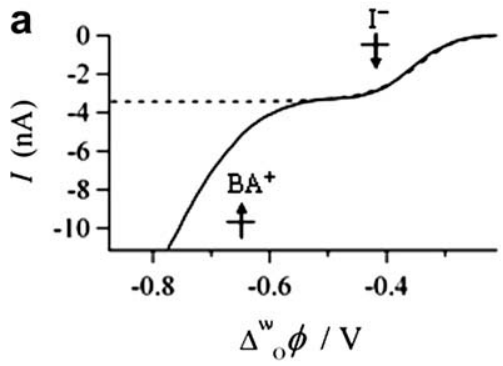

C

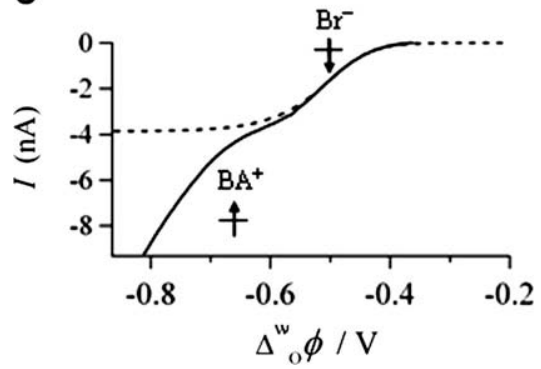

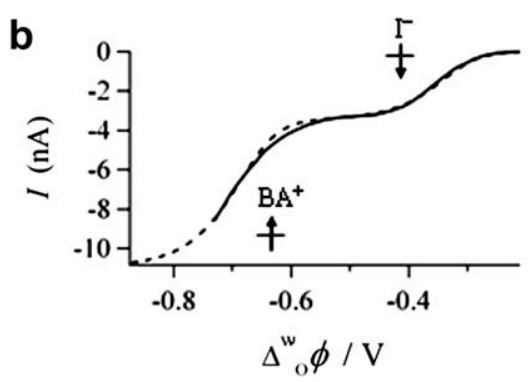

d

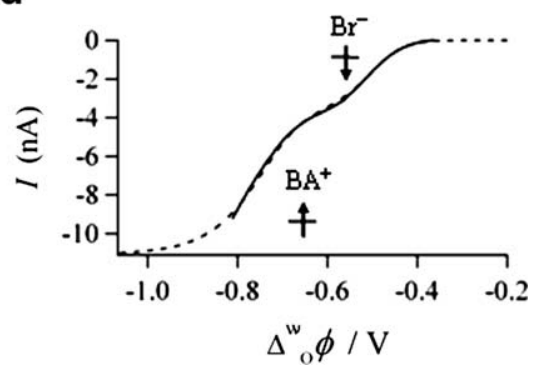

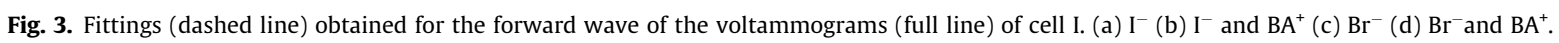


Taking into account such differences, $\mathrm{Cs}^{+}$was chosen in order to study the transfer of $\mathrm{TB}^{+}$considering the $\Delta_{\mathrm{o}}^{\mathrm{w}} \phi_{1 / 2}$ for $\mathrm{Cs}^{+}$reported by other authors (between 0.37 [4] and $0.39 \mathrm{~V}[4,19]$ ). However, in Table 2 , the $\Delta_{\mathrm{o}}^{\mathrm{w}} \phi_{1 / 2}$ obtained is $90 \mathrm{mV}$ higher $(0.48 \mathrm{~V})$. Consequently, it is not surprising that the slope for the transfer of $\mathrm{Cs}^{+}$and $\mathrm{TB}^{-}$is lower than the theoretical value, since the actual difference between the $\Delta_{\mathrm{o}}^{\mathrm{w}} \phi_{1 / 2}$ of $\mathrm{Cs}^{+}$and $\mathrm{TB}^{-}$, is just $0.23 \mathrm{~V}$. Moreover, it is reasonable to expect $\mathrm{Cs}^{+}$can form ion-pairs with $\mathrm{TB}^{-}$, as strongly ionpairing with other hydrophobic anions such as $\mathrm{TPB}^{-}[14,30,32]$ and

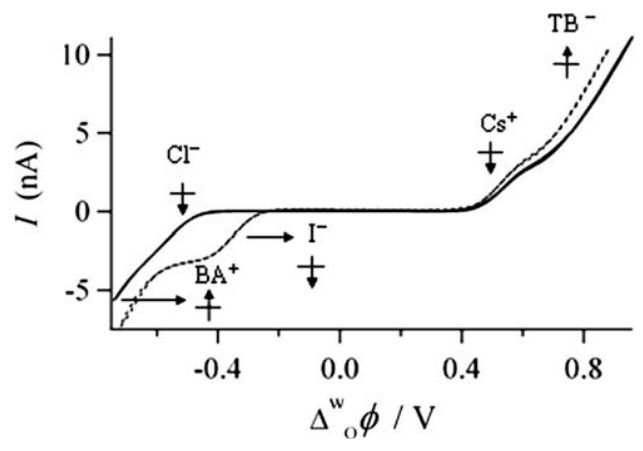

Fig. 4. Cyclic voltammogram obtained at the water|DCE interface with cell III. Scan rate: $10 \mathrm{mV} \mathrm{s}^{-1}$. The potential windows were calibrated with respect to the $\Delta_{0}^{\mathrm{w}} \phi_{1 / 2}$ of the aqueous anions $\mathrm{I}^{-}$or $\mathrm{Cl}^{-}(-0.34 \mathrm{~V}$ and $-0.53 \mathrm{~V} \mathrm{[23]} \mathrm{respectively).}$

Table 2

Results obtained from the fitting using Eq. (4) for cell III. The potential windows were calibrated with respect to the corresponding aqueous anions, i.e. $\mathrm{I}^{-}$or $\mathrm{Cl}^{-}(-0.34 \mathrm{~V}$ [23] and $-0.53 \mathrm{~V}[23]$ respectively).

\begin{tabular}{|c|c|c|c|c|}
\hline \multirow[b]{2}{*}{ Ion } & \multicolumn{2}{|l|}{ CsI } & \multicolumn{2}{|l|}{$\mathrm{CsCl}$} \\
\hline & $\mathrm{Cs}^{+}$ & $\mathrm{I}^{-}$ & $\mathrm{Cs}^{+}$ & $\mathrm{Cl}^{-}$ \\
\hline$I_{\lim }(\mathrm{nA})$ & 3.1 & -3.2 & 2.6 & -3.8 \\
\hline$\Delta_{\mathrm{o}}^{\mathrm{w}} \phi_{1 / 2}(\mathrm{~V})$ & 0.48 & -0.34 & 0.48 & -0.53 \\
\hline$F / R T\left(\mathrm{~V}^{-1}\right)$ & 35.7 & 39.6 & 34.6 & 32.8 \\
\hline$\Delta G_{\mathrm{tr}}^{0^{\prime}, \mathrm{w} \rightarrow \mathrm{o}}\left(\mathrm{kJ} \mathrm{mol}^{-1}\right)$ & 46.3 & 32.8 & 46.3 & 51.1 \\
\hline Ion & $\mathrm{TB}^{-}$ & $\mathrm{BA}^{+}$ & $\mathrm{TB}^{-}$ & $\mathrm{BA}^{+}$ \\
\hline$I_{\lim }(\mathrm{nA})$ & 5.9 & -6.5 & 5.5 & -6.2 \\
\hline$\Delta_{\mathrm{o}}^{\mathrm{w}} \phi_{1 / 2}(\mathrm{~V})$ & 0.71 & -0.67 & 0.71 & -0.70 \\
\hline$F / R T\left(\mathrm{~V}^{-1}\right)$ & 30.1 & 39.6 & 28.2 & 37.6 \\
\hline$\Delta G_{\mathrm{tr}}^{0^{\prime}, \mathrm{w} \rightarrow 0}\left(\mathrm{~kJ} \mathrm{~mol}{ }^{-1}\right)$ & -68.5 & -64.6 & -68.5 & -67.5 \\
\hline
\end{tabular}

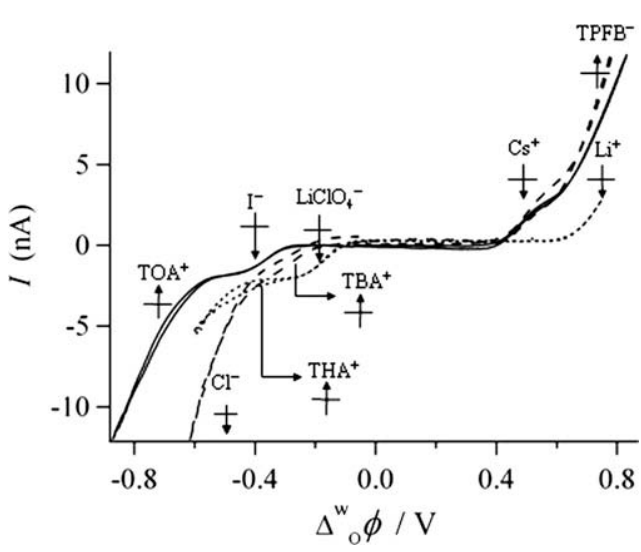

Fig. 5. Cyclic voltammograms obtained at the water|DCE interface with cells IV-VI. Scan rate: $10 \mathrm{mV} \mathrm{s}^{-1}$. The potential windows were calibrated with respect to the $\Delta_{\mathrm{o}}^{\mathrm{w}} \phi_{1 / 2}$ of the corresponding aqueous anions $\mathrm{I}^{-}, \mathrm{Cl}^{-}$and $\mathrm{ClO}_{4}^{-}(-0.34 \mathrm{~V} \mathrm{[23],}-0.53 \mathrm{~V}$ and $-0.15[24]$ respectively).
$\mathrm{TPBCl}^{-}[19,30]$ has been reported for this cation. However, taking into account $\mathrm{TB}^{-}$mainly behaves as a non-coordinating anion [33], the ion pair formation would be much less significant than that with other organic anions (e.g. $\mathrm{TPBCl}^{-}$and $\mathrm{TPB}^{-}$). Accordingly, its influence in the determination of the $\Delta_{0}^{\mathrm{w}} \phi_{1 / 2}$ can be neglected. Furthermore, when comparing the $\Delta_{\mathrm{o}}^{\mathrm{w}} \phi_{1 / 2}$ of $\mathrm{BA}^{+}, \mathrm{I}^{-}$and $\mathrm{Cl}^{-}$obtained using cell II (Table 1 ) with the values obtained for cell I, we can observe that the mentioned decrease of the slope in cell II, does not have a significance effect on the determination of the $\Delta_{\mathrm{o}}^{w} \phi_{1 / 2}$. This suggests that despite the fact that the slope for $\mathrm{TB}^{-}$ is lower than the theoretical value, the $\Delta_{0}^{\mathrm{w}} \phi_{1 / 2}$ determined for this ion is still reliable.

In order to validate the results obtained with the methodology proposed in this work, we studied the transfer of $\mathrm{TBA}^{+}, \mathrm{THA}^{+}$and $\mathrm{TOA}^{+}$from the organic to the aqueous phase using cells IV-VI.

Table 3

Results obtained from the fitting using Eq. (4) for the ions in cells IV-VI. The potential windows were calibrated with respect to the corresponding aqueous anions, i.e. $\mathrm{I}^{-}$, $\mathrm{Cl}^{-}$and $\mathrm{ClO}_{4}^{-}(-0.34 \mathrm{~V}[23],-0.53 \mathrm{~V}[23]$ and -0.15 [24] respectively).

\begin{tabular}{|c|c|c|c|c|c|c|}
\hline \multirow[b]{2}{*}{ Ion } & \multicolumn{2}{|l|}{ ТВАТВ } & \multicolumn{2}{|c|}{ THATB } & \multicolumn{2}{|c|}{ TOАТВ } \\
\hline & $\mathrm{Cs}^{+}$ & $\mathrm{Cl}^{-}$ & $\mathrm{Li}^{+}$ & $\mathrm{ClO}_{4}^{-}$ & $\mathrm{Cs}^{+}$ & $\mathrm{I}^{-}$ \\
\hline$I_{\lim }(\mathrm{nA})$ & 2.7 & -8.1 & 2.0 & -2.4 & 3.0 & -2.1 \\
\hline$\Delta_{\mathrm{o}}^{\mathrm{w}} \phi_{1 / 2}(\mathrm{~V})$ & 0.45 & -0.53 & 0.65 & -0.15 & 0.44 & -0.34 \\
\hline$F / R T\left(\mathrm{~V}^{-1}\right)$ & 37.4 & 38.5 & 35.6 & 39.6 & 38.9 & 39.6 \\
\hline$\Delta G_{\mathrm{tr}}^{0^{\prime}, \mathrm{w} \rightarrow \mathrm{o}}\left(\mathrm{kJ} \mathrm{mol}^{-1}\right)$ & 43.4 & 51.1 & 62.7 & 14.5 & 42.5 & 32.8 \\
\hline Ion & $\mathrm{TB}^{-}$ & $\mathrm{TBA}^{+}$ & $\mathrm{THA}^{+}$ & & $\mathrm{TB}^{+}$ & $\mathrm{TOA}^{+}$ \\
\hline$I_{\lim }(\mathrm{nA})$ & 6.5 & -2.3 & -2.5 & & 7.1 & -6.2 \\
\hline$\Delta_{\mathrm{o}}^{\mathrm{w}} \phi_{1 / 2}(\mathrm{~V})$ & 0.70 & -0.27 & -0.47 & & 0.67 & -0.69 \\
\hline$F / R T\left(\mathrm{~V}^{-1}\right)$ & 35.6 & 37.8 & 39.6 & & 34.8 & 39.6 \\
\hline$\Delta G_{\mathrm{tr}}^{0^{\prime}, \mathrm{w} \rightarrow \mathrm{o}}\left(\mathrm{kJ} \mathrm{mol}^{-1}\right)$ & -68.5 & -27.0 & -45.3 & & -64.6 & -66.6 \\
\hline
\end{tabular}

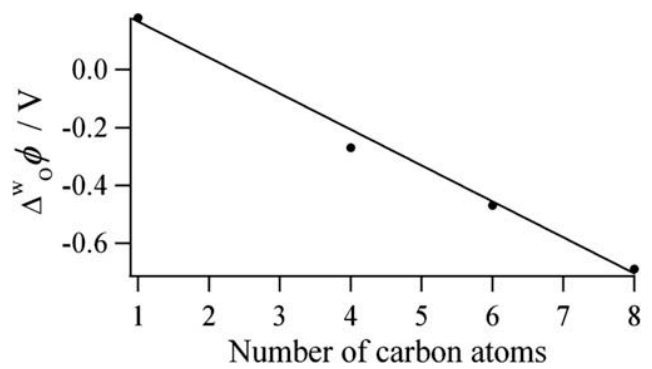

Fig. 6. Correlation between the number of carbon atoms in the ions $\mathrm{TMA}^{+}, \mathrm{TBA}^{+}$, $\mathrm{THA}^{+} \mathrm{TOA}^{+}$their $\Delta_{\mathrm{o}}^{\mathrm{w}} \phi_{1 / 2}$.

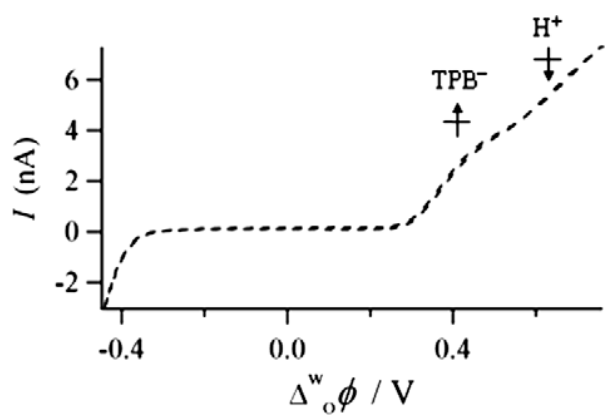

Fig. 7. Cyclic voltammograms obtained at the water|DCE interface with cell VII Scan rate: $10 \mathrm{mV} \mathrm{s}^{-1}$. The potential windows were calibrated with respect to the $\Delta_{\mathrm{o}}^{\mathrm{w}} \phi_{1 / 2}$ of $\mathrm{TPB}^{-}(-0.34 \mathrm{~V})$ [19]. 

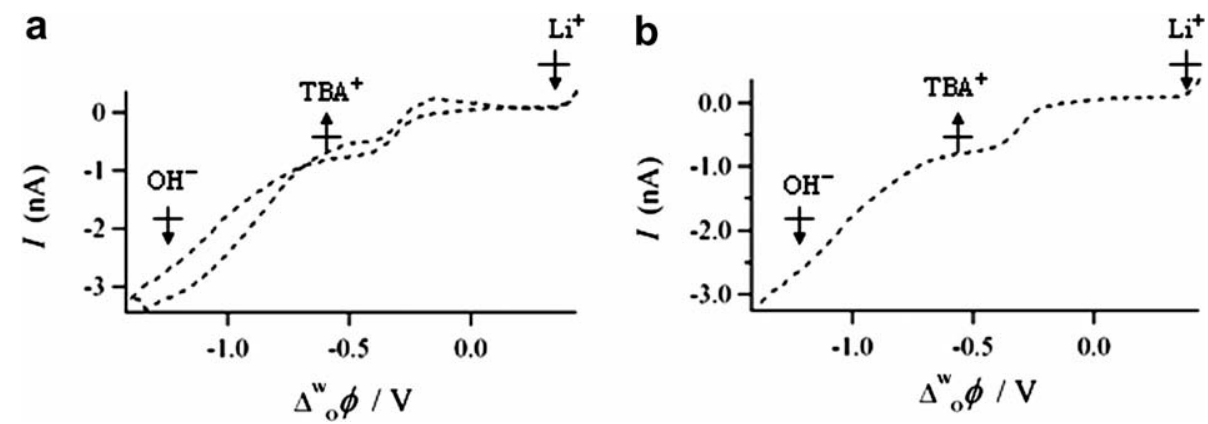

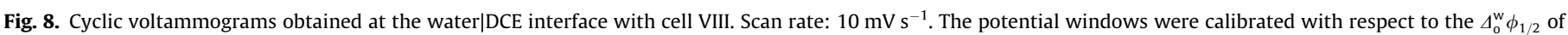
$\mathrm{TBA}^{+}(0.27 \mathrm{~V})$ : (a) full voltammogram (b) forward wave.

Table 4

Results obtained from the fitting using Eq. (4) for cells VII and VIII. The potential windows were calibrated with respect to the $\Delta_{0}^{\mathrm{w}} \phi_{1 / 2}$ of $\mathrm{TPB}^{-}$[19] and $\mathrm{TBA}^{+}$ respectively.

\begin{tabular}{lccccc}
\hline & \multicolumn{2}{c}{ VII } & & \multicolumn{2}{l}{ VIII } \\
\cline { 2 - 3 } \cline { 5 - 6 } Ion & $\mathrm{H}^{+}$ & $\mathrm{TPB}^{-}$ & & $\mathrm{TBA}^{+}$ & $\mathrm{OH}^{-}$ \\
\hline$I_{\mathrm{lim}}(\mathrm{nA})$ & 6.5 & 3.2 & & -0.8 & -1.2 \\
$\Delta_{\mathrm{o}}^{\mathrm{w}} \phi_{1 / 2,}(\mathrm{~V})$ & 0.58 & 0.34 & & -0.27 & -0.70 \\
$F / R T\left(\mathrm{~V}^{-1}\right)$ & 31.2 & 39.6 & & 32.0 & 33.0 \\
$\Delta G_{\mathrm{tr}}^{0^{\prime}, \mathrm{w} \rightarrow \mathrm{o}}\left(\mathrm{kJ} \mathrm{mol}^{-1}\right)$ & 56.0 & -33.0 & & -26.0 & 67.6 \\
\hline
\end{tabular}

Fig. 5 and Table 3 summarize the obtained results. For the transfer of $\mathrm{THA}^{+}$and $\mathrm{TOA}^{+}$, the slope is equal to the theoretical value, which agrees with the hypothesis concerning the separation between transfer potentials, given that such separation between these ions and the corresponding ion transferred from the aqueous phase $\left(\mathrm{ClO}_{4}^{-}\right.$and $\mathrm{I}^{-}$respectively) is around $0.35 \mathrm{~V}$. On the other hand, for the transfer of $\mathrm{TBA}^{+}$, such difference is only $0.27 \mathrm{~V}$ explaining the decrease of the slope. The transfer of $\mathrm{Cs}^{+}$and $\mathrm{TB}^{-}$follows the same behavior observed in cell III for these ions.

Fig. 6 correlates the number of carbon atoms of the series $\mathrm{TMA}^{+}$, $\mathrm{TBA}^{+}, \mathrm{THA}^{+}$and $\mathrm{TOA}^{+}$and their $\Delta_{\mathrm{o}}^{\mathrm{w}} \phi_{1 / 2}$. As it was expected, the correlation is linear, confirming the reliability of the results.

Figs. 7 and 8 and Table 4 summarize the results obtained for the cell VII and VIII.

In order to avoid the interference from $\mathrm{CO}_{2}$ in the determination of the $\Delta_{0}^{\mathrm{w}} \phi_{1 / 2}$ for $\mathrm{OH}^{-}$, the water used to prepare the solution of $\mathrm{LiOH}$ was degassed with argon in order to displace the $\mathrm{CO}_{2}$ and all the solutions employed were also freshly prepared. Moreover, all the values calculated for hydroxide ions were extracted from the first scan of the voltammogram (Fig. 8). Thus, our experiments were proved to be reproducible and therefore any possible interference from the reaction between $\mathrm{CO}_{2}$ and $\mathrm{OH}^{-}$can be ruled out.

The slopes in the case of $\mathrm{OH}^{-}$(Table 4), are lower than the theoretical value, which could be due to the adsorption of TBAOH at the interface. This explains the big difference between the forward peak and the reverse peak and the low limiting current obtained for the $\mathrm{TBA}^{+}$in comparison with the value obtained in the cell IV (Table 3 ). However, taking into account that the fitting is always made with the forward peak, we can say that the value of $\Delta_{0}^{\mathrm{w}} \phi_{1 / 2}$ determined for the $\mathrm{OH}^{-}$is likely to be reliable. In the case of $\mathrm{H}^{+}$ the value of $\Delta_{0}^{\mathrm{w}} \phi_{1 / 2}$ determined is in agreement with the value reported $(0.54 \mathrm{~V}[23])$.

Knowing the $\Delta G_{\mathrm{tr}}^{0^{\prime}, \mathrm{w} \rightarrow \mathrm{DCE}}$ of $\mathrm{H}^{+}$and $\mathrm{OH}^{-}$(Table 4) the dissociation constant of water in DCE ( $\Delta G_{\text {diss,water }}^{\mathrm{DCE}}$ ) can be calculated as follows:

$\Delta G_{\text {diss,water }}^{\mathrm{DCE}}=\Delta G_{\text {diss }, \text { water }}^{\text {water }}+\Delta G_{\mathrm{tr}, \mathrm{H}^{+}}^{0^{\prime}, \mathrm{W} \rightarrow \mathrm{DCE}}+\Delta G_{\mathrm{tr}, \mathrm{OH}^{-}}^{0^{\prime}, \mathrm{DCE}}-\Delta G_{\mathrm{tr}, \mathrm{water}}^{0^{\prime}, \mathrm{W} \rightarrow \mathrm{DE}}$

where $\Delta G_{\text {tr.water }}^{0^{\prime}, \mathrm{W} \rightarrow \text { DCE }}$ is the standard Gibbs energy of transfer of $\mathrm{H}_{2} \mathrm{O}$ across the water/DCE interface $15.4 \mathrm{~kJ} \mathrm{~mol}^{-1}$ [34]. As a result, the
$\Delta G_{\text {diss.water }}^{\mathrm{DCE}}$ was found to be $187 \mathrm{~kJ} \mathrm{~mol}^{-1}$ and consequently, the dissociation of water in DCE would be $5.6 \times 10^{-34}$. This value has special relevance in reactions in which water and DCE are at the equilibrium and the protons are being consumed in the organic phase. In such a way, the initial concentration of protons without any common ion or application of an external potential can be estimated.

The fact that the $\Delta_{\mathrm{o}}^{\mathrm{w}} \phi_{1 / 2}$ determined for the ions studied in this work are in agreement with the values reported, and that the dispersion was just $\pm 4 \mathrm{mV}$ in all studied systems, indicate that the methodology proposed in this work allows determining reliable values of $\Delta G_{\mathrm{tr}}^{0^{\prime}}$ for highly hydrophobic or hydrophilic ions.

\section{Conclusions}

In this work, Wilke's methodology to determine the $\Delta G_{\mathrm{tr}}^{0^{\prime}}$ of highly lipophilic and hydrophilic ions, using a low concentration of supporting electrolyte in the organic phase and not supporting electrolyte in the aqueous phase was applied and validated. In order to obtain reliable results, the separation between the transfer potentials of ions transferring consecutively was found to be between 0.35 and $0.45 \mathrm{~V}$. In addition, the minimum concentration of supporting electrolyte in the organic phase must be $0.5 \mathrm{mM}$ in order to avoid a non-negligible IR drop resistance in the system. The obtained values for the $\mathrm{H}^{+}$and $\mathrm{OH}^{-}$allowed us to calculate the dissociation constant of water in DCE.

\section{Acknowledgement}

This work was supported by the Swiss Natural Science Foundation, Project FNS 200020-124466, electrochemical methodology for the study of peptide lipid interactions.

\section{References}

[1] A.-K. Kontturi, K. Kontturi, L. Murtomäki, D.J. Schiffrin, J. Chem. Soc., Faraday Trans. 86 (1990) 819-822.

[2] S. Peulon, V. Guillou, M. L'Her, J. Electroanal. Chem. 514 (2001) 94-102.

[3] A.-K. Kontturi, K. Kontturi, L. Murtomäki, J. Chem. Soc., Faraday Trans. 86 (1990) 931-936.

[4] Z. Samec, V. Marecek, M.P. Colombini, J. Electroanal. Chem. 257 (1988) 147154.

[5] Y. Shao, H.H. Girault, J. Electroanal. Chem. 334 (1992) 203-211.

[6] S. Wilke, J. Electroanal. Chem. 504 (2001) 184-194.

[7] J.A. Campbell, H.H. Girault, J. Electroanal. Chem. 266 (1989) 465-469.

[8] V. Sladkov, V. Guillou, S. Peulon, M. L’Her, J. Electroanal. Chem. 573 (2004) 129-138.

[9] S. Wilke, M.D. Osborne, H.H. Girault, J. Electroanal. Chem. 436 (1997) 53-64

[10] S. Wilke, T. Zerihun, Electrochim. Acta 44 (1998) 15-22.

[11] A. Lhotský, K. Holub, P. Neuil, V. Marecek, J. Chem. Soc., Faraday Trans. 92 (1996) 3851-3857.

[12] H. Ohde, A. Uehara, Y. Yoshida, K. Maeda, S. Kihara, J. Electroanal. Chem. 496 (2001) 110-117.

[13] G. Taylor, H.H.J. Girault, J. Electroanal. Chem. 208 (1986) 179-183.

[14] B. Quinn, R. Lahtinen, L. Murtomäki, J. Electroanal. Chem. 460 (1999) 149-159. 
[15] P.D. Beattie, A. Delay, H.H. Girault, J. Electroanal. Chem. 380 (1995) 167-175.

[16] B. Quinn, R. Lahtinen, L. Murtomäki, K. Kontturi, Electrochim. Acta 44 (1998) 47-57.

[17] K.B. Oldham, J. Electroanal. Chem. 250 (1988) 1-21.

[18] M.C. Osborne, Y. Shao, C.M. Pereira, H.H. Girault, J. Electroanal. Chem. 364 (1994) 155-161.

[19] Y. Shao, A.A. Stewart, H.H. Girault, J. Chem. Soc., Faraday Trans 87 (1991) 2593-2597.

[20] I. Hatay, B. Su, F. Li, M.A. Méndez, T. Khoury, C.P. Gros, J.-M. Barbe, M. Ersoz, Z Samec, H.H. Girault, J. Am. Chem. Soc. 131 (2009) 13453-13459.

[21] K.B. Oldham, J. Electroanal. Chem. 337 (1992) 91-126.

[22] J. Czapkiewicz, B. Czapkiewicz-Tutaj, J. Chem. Soc., Faraday Trans. 1 (76) (1980) 1663-1668.

[23] A. Sabela, V. Marecek, Z. Samec, R. Fuoco, Electrochim. Acta 37 (1992) 231 235.

[24] T. Wandlowski, V. Marecek, Z. Samec, Electrochim. Acta 35 (1990) 1173-1175.
[25] F.O. Laforge, T. Kakiuchi, F. Shigematsu, M.V. Mirkin, J. Am. Chem. Soc. 22 (2006) 10705-10710.

[26] T. Kakiuchi, N. Tsujioka, J. Electroanal. Chem. 599 (2007) 209-212.

27] R. Ishimatsu, N. Nishi, T. Kakiuchi, Chem. Lett. 36 (2007) 1166-1167.

[28] R. Ishimatsu, Y. Kitazumi, N. Nishi, T. Kakiuchi, J. Phys. Chem. B 113 (2009) 9321-9325.

[29] J. Newman, K.E. Thomas-Alyea, Electrochemical Systems, Springer, Berlin, 2004. pp. 459-490.

[30] K. Maeda, S. Kihara, M. Suzuki, M. Matsui, J. Electroanal. Chem. 295 (1990) 183-201.

[31] A.-K. Kontturi, K. Kontturi, L. Murtomäki, D.J. Schiffrin, J. Chem. Soc., Faraday Trans. 90 (1994) 2037-2041.

[32] E. Makrlík, L.Q. Hung, J. Electroanal. Chem. 158 (1983) 285-293.

[33] I. Krossing, I. Raabe, Angw. Chem. Int. Edit. 43 (2004) 2066-2090.

[34] Z. Samec, Rev. Polaro. Kyoto 55 (2009) 75 